\title{
APAKAH AGRESIVITAS PAJAK MENURUNKAN TINGKAT KEINFORMATIFAN LABA PERUSAHAAN?
}

\author{
Pria Aji Pamungkas ${ }^{1}$ \\ Politeknik Keuangan Negara STAN \\ priaajipamungkas@gmail.com \\ Amrie Firmansyah ${ }^{2}$ \\ Politeknik Keuangan Negara STAN \\ amrie.firmansyah@gmail.com
}

Diterima 6 Mei 2021

Disetujui 13 Juni 2021

\begin{abstract}
This research aims to examine the association between tax aggressiveness and the level of earnings informativeness. This study examines whether tax aggressiveness is being responded to by the market. This study's methodology is a quantitative approach with multiple linear regression models and panel data. The sample employed in this study is trading sector companies listed on the Indonesia Stock Exchange (IDX). The type of data used in this study is secondary data sourced from financial statements, stock price information, and annual reports from 2017 to 2019. The sample selection using a purposive sampling method with the number of samples amounted to 48 firm-year. This study suggests that tax aggressiveness is negatively associated with the level of earnings informativeness. The complexity of the company's tax aggressiveness activities makes it more difficult for investors to understand the quality of earnings reported by the company.
\end{abstract}

Keywords: Tax Aggressiveness; Tax Avoidance; Earnings Informativeness; ERC; Market Responsiveness

\section{PENDAHULUAN \\ 1.1 Latar Belakang}

Laporan keuangan merupakan media yang menyediakan informasi lengkap terkait dengan aktivitas perusahaan. Informasi tersebut akan digunakan oleh investor dalam menilai dan menganalisis risiko serta tingkat pengembalian investasi suatu perusahaan, termasuk dalam memprediksi aliran kas masa depan dan mengantisipasi future earnings (Kubata et al., 2013). Informasi laba oleh perusahaan merupakan salah satu informasi yang penting dan relevan bagi para pemangku kepentingan dalam rangka pengambilan keputusan. Informasi tersebut dimanfaatkan oleh investor untuk menilai kinerja perusahaan, melakukan prediksi atas laba di masa depan dan estimasi atas risiko investasi atau risiko kredit (Kubata et al., 2013). Informasi yang terdapat di laporan keuangan dapat dianggap "berguna" jika memiliki implikasi valuasi, yaitu jika menyebabkan investor menyesuaikan harga saham (Zimmerman, 1983). Earnings response coefficient (ERC) dapat dijadikan sebagai alat untuk menilai kandungan informasi dalam laba yang dilaporkan karena ERC mampu mengidentifikasi dan memberikan penjelasan atas perbedaan respon pasar saat laba diumumkan melalui laporan keuangan (Kubata et al., 2013). Hubungan antara laba akuntansi dan tingkat pengembalian (return) saham dapat digunakan untuk menilai sebuah perusahaan. Laba dapat dikatakan 
memiliki kandungan informasi jika laba tersebut dapat mencerminkan return saham. Informasi laba yang terdapat dalam laporan keuangan seharusnya memiliki nilai prediktif bagi investor dalam pengambilan keputusan investasi (Firmansyah et al., 2020).

Hasil pengujian Ball \& Brown (1968) menunjukkan bahwa semakin besar unexpected earnings yang dilaporkan oleh perusahaan akan direspon dengan meningkatnya abnormal return. Penelitian yang menguji hubungan return dan laba selanjutnya berkembang menjadi ERC yaitu pengaruh dari unexpected earnings terhadap return saham yang diukur sebagai slope dalam regresi abnormal return dan unexpected return (Kubata et al., 2013). Respon laba yang menurun, atau respon yang lebih lemah dari yang diharapkan secara teoritis, dapat diartikan sebagai berkurangnya keinformatifan laba dan kualitas laba (Firmansyah, 2017). Pada awal tahun 2021, harga saham PT Perusahaan Gas Negara Tbk (PGAS) ditutup auto reject bawah (ARB) di hari pertama perdagangan bursa tahun 2021 akibat kekalahan sengketa pajak senilai Rp 3,06 triliun (Kontan, diakses 07 Februari 2021). Di menit awal perdagangan sesi I Senin (04/01/2021), harga saham PGAS anjlok ke posisi Rp 1.540 per saham, alias turun $6,95 \%$ dari penutupan akhir tahun lalu. Kegiatan agresivitas pajak yang dilakukan oleh perusahaan direspon oleh investor yang tercermin dari pergerakan harga saham.

Laba rugi merupakan item dalam laporan keuangan yang biasanya menjadi pusat perhatian bagi investor dalam pengambilan keputusan. Di satu sisi, laba rugi merupakan informasi yang mencerminkan kinerja perusahaan yang dijalankan oleh perusahaan dalam aktivitas operasinya. Di sisi lain, laba rugi yang disajikan menjadi kurang berkualitas apabila terdapat adanya diskresi dari manajer dalam penyajian angka-angka akuntansi (Sakessia \& Firmansyah, 2020). Dechow \& Schrand (2004) menyatakan bahwa karakteristik laba yang berkualitas seperti laba dapat menjadi ukuran yang baik untuk mengevaluasi kinerja perusahaan di masa lalu, secara akurat mencerminkan kinerja operasi perusahaan saat ini, dan mampu menjadi indikator yang relevan untuk memprediksi kinerja operasi perusahaan di masa depan. Laba yang kurang berkualitas dapat mengakibatkan kurang mencerminkan harga saham, return saham, atau bahkan risiko saham (Firmansyah et al., 2020), sehingga respon pasar menjadi berkurang. Kebijakan-kebijakan tertentu yang tertuang berdasarkan data dan informasi yang diberikan kepada publik dapat menjadi sinyal baik atau sinyal buruk kepada investor dan calon investor di pasar modal. Oleh karena itu, keinformatifan laba yang dapat digunakan dalam pengambilan keputusan investasi terkait dengan tingkat pengembalian saham perlu untuk diinvestigasi lebih lanjut.

Penelitian-penelitian sebelumnya telah mendokumentasikan faktor-faktor yang berpengaruh terhadap ERC. Collins \& Kothari (1989) menunjukkan bahwa persistensi laba, pertumbuhan perusahaan, leverage, dan risiko berpengaruh terhadap ERC. Lasmida et al. (2020) menemukan bahwa leverage berpengaruh positif terhadap ERC. Temuan ini selaras dengan penelitian Pandana \& Santioso (2020) yang menemukan bahwa semakin besar ukuran perusahaan dan leverage dapat meningkatkan ERC. Penelitian Rahmawati \& Asyik (2019) menyimpulkan bahwa semakin besar profitabilitas dan peningkatan pertumbuhan perusahaan direspon dengan tingkat ERC yang semakin besar. Lestari (2018) menemukan bahwa kualitas auditor berpengaruh positif terhadap keinformatifan laba. Yanti \& Takwa (2020) menyimpulkan bahwa struktur kepemilikan perusahaan dan kualitas audit tidak berpengaruh terhadap keinformatifan laba (2020). Ihdina et al. (2019) mememukan bahwa tanggung jawab sosial perusahaan dan profitabilitas berpengaruh positif terhadap keinformatifan laba. Sementara itu, Firmansyah (2017) menemukan bahwa income smoothing tidak berpengaruh terhadap keinformatifan laba, sedangkan real earnings management berpengaruh positif terhadap keinformatifan laba. 
Keinformatifan laba menunjukkan seberapa besar laba dapat digunakan dalam pengambilan keputusan investasi di pasar modal. Kondisi tersebut juga dipengaruhi oleh kebijakan perusahaan tertentu yang tercermin dalam laporan keuangan. Salah satu kebijakan perusahaan yaitu menerapkan berbagai strategi pajak untuk dapat menghasilkan penghematan pajak secara eksplisit. Dalam kondisi ceteris paribus, penghematan pajak ini akan menyebabkan peningkatan arus kas bersih dan pendapatan setelah pajak, yang pada akhirnya memiliki efek positif pada nilai perusahaan (Desai \& Dharmapala, 2009). Namun, perencanaan pajak perusahaan juga menimbulkan biaya; baik eksplisit maupun implisit (Scholes et al., 2009). Adanya potensi penurunan keinformatifan laba merupakan contoh jenis biaya non-pajak implisit yang sebelumnya diabaikan terkait dengan aktivitas penghindaran pajak perusahaan. Pada tingkat konseptual, aktivitas perencanaan pajak yang termasuk dalam konstruksi penghindaran pajak ditujukan untuk mengurangi beban pajak eksplisit dengan mengelola penghasilan kena pajak. Laba akuntansi setelah pajak ini kemudian dilaporkan kepada pemegang saham yang mencoba mendapatkan informasi relevan terkait laba perusahaan tersebut.

Balakrishnan et al. (2019) membuktikan bahwa penghindaran pajak dapat mengurangi keinformatifan laba yang dilaporkan. Penghindaran pajak mampu mengurangi transparansi keuangan dan organisasi perusahaan yang pada akhirnya juga dapat merusak keinformatifan laba bersih (Kubata et al., 2013). Umumnya, praktik penghindaran pajak yang kompleks dapat memengaruhi pendapatan bersih di dua titik tertentu (Wagener \& Watrin, 2014). Pertama, biaya pajak itu sendiri dapat berkurang kandungan informasinya ketika perusahaan melakukan perencanaan pajak yang lebih agresif. Kedua, penghindaran pajak yang ekstensif mengurangi keinformatifan laba bersih pada tingkat penghasilan sebelum pajak. Hal ini dikarenakan penghindaran pajak dapat mengganggu kemampuan investor untuk sepenuhnya memahami substansi mendasar dari kinerja perusahaan yang tercermin dalam pendapatan sebelum pajak.

Balakrishnan et al. (2011) menyatakan bahwa penghindaran pajak secara signifikan mengurangi transparansi perusahaan dengan meningkatkan kompleksitas keuangan dan organisasi perusahaan. Namun, praktik penghindaran pajak terkadang sulit dipahami oleh pihak eksternal, terutama dalam kasus grup perusahaan besar yang menerapkan berbagai strategi perpajakan yang kompleks secara bersamaan. Penelitian Kubata et al. (2013) menemukan pengaruh negatif penghindaran pajak terhadap keinformatifan laba. Perusahaan yang terlibat dalam tingkat penghindaran pajak yang relatif tinggi (tercermin dari tarif pajak efektif yang relatif rendah) menunjukkan pengaruh negatif terhadap keinformatifan laba. Hasil pengujian tersebut sesuai dengan penelitian Kothari \& Sloan (1992). Penelitian Suharti \& Arieftiara (2019) tidak dapat membuktikan adanya pengaruh secara simultan antara agresivitas pelaporan keuangan dan agresivitas pelaporan pajak terhadap ERC. Adanya inkonsistensi pengujian sebelumnya, pengujian agresivitas pajak terhadap keinformatifan laba perlu diinvestigasi lebih lanjut.

Penelitian ini bertujuan untuk menginvestigasi pengaruh agrevisitas pajak terhadap keinformatifan laba. Suharti \& Arieftiara (2019) menguji apakah efek simultan dari agresivitas pelaporan keuangan dan agresivitas pajak dapat mempengaruhi tingkat earnings informativeness perusahaan-perusahaan yang terdaftar di Bursa Efek Indonesia. Namun, penelitian tersebut tidak dapat membuktikan adanya pengaruh secara simultan antara agresivitas pelaporan keuangan dan agresivitas pelaporan pajak terhadap ERC. Berbeda dengan Suharti \& Arieftiara (2019) yang menggunakan beda permanen untuk mengukur agresivitas pajak, penelitian ini menggunakan Current Book Effective Tax Rate (CETR). Dalam praktiknya, perusahaan tidak mengungkapkan secara eksplisit berapa jumlah pajak 
yang sebenarnya dibayar, namun perusahaan seharusnya memisahkan berapa jumlah beban pajak kini dan beban pajak tangguhan perusahaan pada suatu periode. Penggunaan beban pajak kini sebagai ukuran CETR mempertimbangkan adanya beda temporer sehingga dapat menangkap agresivitas pajak dengan lebih baik (Dunbar et al., 2016).

\subsection{Tinjauan Pustaka}

\subsubsection{Signaling Theory (Teori Sinyal)}

Teori sinyal berusaha menjelaskan perilaku di antara dua pihak, baik secara individu maupun dalam organisasi, yang memiliki perbedaan dalam mendapatkan akses atas suatu informasi (Connelly et al., 2011). Asimetri informasi dapat terjadi ketika manajer perusahaan sebagai pengirim sinyal berusaha untuk mengungkapkan berbagai informasi kepada para pemangku kepentingan sebagai penerima sinyal (Karasek \& Bryant, 2015). Penyajian informasi oleh manajer perusahaan dapat mencakup catatan, keterangan atau gambaran mengenai kondisi perusahaan pada masa lalu, kinerja perusahaan di masa sekarang atau prospek perusahaan di masa depan. Perbedaan informasi yang dimiliki oleh investor dan manajer perusahaan dapat menyebabkan terjadinya asimetri informasi akibat keterbatasan akses investor terhadap sumber informasi perusahaan (Septilestari et al., 2018). Ketika informasi yang dimiliki oleh investor kurang relevan dalam menggambarkan kondisi perusahaan yang sebenarnya, investor akan menganggap informasi yang dilaporkan oleh manajemen tersebut menjadi kurang informatif. Respon investor tersebut akan berdampak pada turunnya harga saham perusahaan.

Berdasarkan teori sinyal, kebijakan manajemen untuk mengungkapkan berbagai informasi melalui laporan keuangan baik yang wajib maupun sukarela dapat menurunkan tingkat asimetri informasi (Firmansyah \& Yusuf, 2020). Dalam upaya mengungkapkan informasi mengenai kondisi perusahaan, manajemen memiliki diskresi untuk menyajikan informasi yang kemungkinan besar akan direspon dengan baik oleh pelaku pasar dan investor. Reaksi pasar yang beragam akibat adanya sinyal yang diberikan oleh manajemen tersebut dapat digunakan untuk menilai kinerja perusahaan. Ketika informasi diumumkan, pelaku pasar dan investor akan menginterpretasikan dan menganalisis informasi tersebut sebagai sinyal baik (good news) atau sinyal buruk (bad news) (Dewi \& Ekadjaja, 2020). Jika merupakan sinyal baik, maka investor akan menganggap bahwa perusahaan cenderung memiliki prospek yang menjanjikan. Permintaan saham perusahaan oleh investor akan semakin tinggi sehingga harga saham juga akan meningkat. Sebaliknya, ketika sinyal dianggap sebagai suatu kabar buruk, respon negatif investor dapat mengakibatkan turunnya harga saham.

\subsubsection{Penelitian Terdahulu}

Kubata et al. (2013) menguji pengaruh penghindaran pajak terhadap earnings informativeness (yang diproksikan melalui ERC). Pengurangan dalam keinformatifan laba dapat menimbulkan biaya bukan pajak yang sebelumnya diabaikan terkait dengan perencanaan pajak perusahaan. Hasil penelitian ini menjelaskan bahwa tingkat penghindaran pajak yang lebih tinggi berpengaruh terhadap menurunnya tingkat earnings informativeness secara signifikan. Penentuan harga saham oleh pasar secara keseluruhan untuk perusahaan penghindar pajak kurang responsif terhadap informasi laba yang tidak terduga. Hal ini menunjukkan bahwa manajemen perusahaan mungkin tidak dapat sepenuhnya mengkompensasi potensi kerugian dalam earnings informativeness yang terkait dengan penghindaran pajak.

Penelitian Suharti \& Arieftiara (2019) menguji apakah efek simultan dari agresivitas pelaporan keuangan dan agresivitas pajak dapat mempengaruhi tingkat earnings 
informativeness perusahaan-perusahaan yang terdaftar di Bursa Efek Indonesia. Ketika seorang manajer melakukan keleluasaan berupa agresivitas pelaporan keuangan, maka kandungan informasi laba rugi tidak dapat mencerminkan kondisi perusahaan yang sebenarnya. Bukti empiris menyatakan bahwa agresivitas laporan keuangan dapat menurunkan kekuatan informasi laba (Hanlon \& Slemrod, 2009). Lebih lanjut, Hanlon \& Slemrod, (2009) menemukan bahwa LBTD (laba akuntansi lebih tinggi dari laba fiskal) terbukti menurunkan ekspektasi investor terhadap kualitas laba perusahaan. Melalui laporan laba rugi perusahaan, pemangku kepentingan dapat mengevaluasi dan memprediksi kejadian di masa lalu, sekarang dan masa depan.

Hanlon et al. (2008) menyebutkan bahwa laporan keuangan yang disusun dengan standar akuntansi yang lebih mengikuti aturan perpajakan (book-tax conformity) terbukti menurunkan keinformatifan laba yang dilaporkan kepada pemegang saham. Bagi pemegang saham, laporan keuangan yang lebih mencerminkan aturan perpajakan tidak relevan untuk pengambilan keputusan investasi. Senada dengan Hanlon, Atwood et al. (2010) menemukan bahwa peningkatan kesesuaian catatan akuntansi-pajak berdampak pada penurunan hubungan antara laba akuntansi yang dilaporkan dengan arus kas masa depan. Perusahaan yang melakukan manajemen laba dengan cara menurunkan laba akuntansi (income-decreasing earnings management) membuat tingkat keinfromatifan laba menurun.

Desai \& Dharmapala (2009) menjelaskan bahwa penghindaran pajak umumnya merupakan fungsi dari tata kelola perusahaan dan investor dari perusahaan yang memiliki governance yang baik memiliki sentimen positif dengan upaya penghindaran pajak perusahaan. Kim et al., (2011) meneliti perusahaan di AS antara 1995 sampai 2008 dan menemukan bahwa penghindaran pajak perusahaan secara positif berpengaruh terhadap risiko jatuhnya harga saham pada tingkat perusahaan. Lietz (2013) membangun indeks opasitas perusahaan dan menyarankan dengan adanya penurunan transparansi akan mengurangi kualitas laba bagi pemegang saham dengan adanya penghindaran pajak. Balakrishnan et al. (2011) menyelidiki potensi masalah transparansi keuangan yang mungkin terkait dengan adanya perencanaan pajak yang agresif oleh suatu perusahaan. Hasil penelitiannya menunjukkan bahwa penghindaran pajak dapat meningkatkan kekaburan (opaqueness) dalam lingkungan pelaporan keuangan perusahaan secara keseluruhan. Kekaburan ini dapat menyebabkan kesulitan bagi pemegang saham untuk mengidentifikasi sumber dan persistensi pendapatan dan arus kas. Namun, Balakrishnan et al. (2011) tidak secara langsung menyelidiki keinformatifan laba, dimana terbukti secara signifikan terganggu oleh adanya upaya penghindaran pajak.

\subsubsection{Pengembangan Hipotesis}

Informasi mengenai laba dapat menunjukkan suatu sinyal tertentu kebijakan tertentu manajer kepada investor. Laba yang informatif dapat digunakan oleh pemegang saham dalam pengambilan keputusan. Keinformatifan laba menggambarkan kemampuan laba yang dilaporkan untuk membantu pemegang saham dalam proses menilai harga saham perusahaan dalam keputusan investasi (Dechow et al., 2010). Kubata et al. (2013) menyatakan bahwa potensi kerugian dalam keinformatifan laba sebagai jenis biaya bukan pajak yang sebelumnya diabaikan, namun signifikan terkait dengan penghindaran pajak perusahaan. Penghindaran pajak perusahaan dapat menurunkan pendapatan kena pajak tetapi juga beban pajak yang dicatat untuk tujuan akuntansi keuangan, yang selanjutnya berdampak pada laba bersih setelah pajak (Jananto \& Firmansyah, 2019; Firmansyah \& Triastie, 2020).

Penghindaran pajak sering kali membutuhkan penggunaan strategi dan transaksi pajak yang sulit dipahami oleh pihak eksternal terutama investor. Ketika investor tidak dapat 
dengan jelas mengidentifikasi pengaruh penghindaran pajak pada laba yang dilaporkan, laba menjadi kurang berguna dalam menentukan nilai perusahaan (Kubata et al., 2013). Secara lebih umum, struktur penghindaran pajak yang rumit (misalnya struktur grup perusahaan yang kompleks) dapat semakin mengganggu transparansi pelaporan keuangan secara keseluruhan, yang menghambat kemampuan investor untuk memperoleh informasi yang komprehensif dan berguna untuk keputusan dari laba yang dilaporkan perusahaan. Di luar masalah transparansi yang terkandung dalam penghindaran pajak yang mungkin secara umum tidak disengaja dan tidak diinginkan (dan berpotensi ditanggapi dengan pengungkapan tambahan), beberapa manajer mungkin juga terlibat dalam penghindaran pajak karena alasan ekstraksi sewa oportunistik (Desai \& Dharmapala, 2009).

Dalam kasus ini, orang dalam perusahaan mungkin sebenarnya memiliki motif intrinsik untuk dengan sengaja menjaga strategi perpajakan mereka tidak transparan, sehingga menciptakan (atau mempertahankan) ketidakjelasan yang disebabkan oleh penghindaran pajak sehingga diharapkan pada akhirnya mempengaruhi keinformatifan laba. Selain itu, perusahaan yang lebih agresif terhadap pajak kemungkinan besar terlibat dalam transaksi yang menunjukkan ketidakpastian yang lebih tinggi. Karena pendapatan setelah pajak kemungkinan menjadi kurang persisten di perusahaan yang melakukan penghindaran pajak agresif, menjadi lebih sulit bagi pemegang saham untuk memperkirakan dengan andal konsekuensi penghindaran pajak saat ini dan di masa depan. Sehingga, informasi terkait laba menjadi kurang informatif dalam menilai harga saham suatu perusahaan (Kubata et al., 2013). Bahkan jika manajer memiliki informasi yang tersedia untuk memperkirakan kemungkinan hasil dari posisi pajak yang tidak pasti, mereka mungkin tidak bersedia untuk mengungkapkannya sepenuhnya kepada investor mereka. Semua informasi yang diungkapkan secara publik juga akan tersedia untuk dan dapat diharapkan melemahkan posisi perusahaan dalam negosiasi dengan otoritas pajak dan/atau memicu audit pajak lebih lanjut yang tidak diinginkan.

Kubata et al. (2013) membuktikan bahwa dampak dari penghindaran pajak dapat berpengaruh pada dua titik utama tingkat keinformatifan laba, yaitu pada beban pajak dan pendapatan sebelum pajak. Pertama, penghindaran pajak diharapkan dapat mempengaruhi keinformatifan beban pajak itu sendiri. Jika aktivitas penghindaran pajak dan implikasi pastinya terhadap kinerja perusahaan sulit untuk dipahami, investor kemungkinan dihadapkan pada laba bersih yang kurang informatif; sisa pos yang tersisa setelah dikurangi dengan beban pajak (yang mengalami penurunan nilai). Selain itu, perusahaan yang melakukan upaya penghindaran pajak agresif mungkin bersedia mengambil risiko pajak yang signifikan untuk mencapai pengurangan pajak yang diinginkan. Dalam kasus tersebut, pemegang saham mungkin memiliki kesulitan yang lebih besar untuk menilai apakah biaya pajak yang lebih rendah akan berkelanjutan di masa depan. Secara keseluruhan, laba bersih yang dilaporkan mungkin menunjukkan konten informasi yang lebih rendah karena efek dari adanya beban pajak yang dikelola secara rumit.

Kedua, penghindaran pajak secara langsung atau tidak langsung mengurangi sifat keinformatifan pendapatan sebelum pajak (EBT). Kompleksitas organisasi dan pelaporan keuangan terkait dengan penghindaran pajak dapat mengganggu kemampuan investor untuk menilai dan memahami substansi ekonomi sebenarnya yang mendasari perusahaan, yaitu kinerja operasi yang tercermin dari laba yang dilaporkan sebelum pajak. Strategi penghindaran pajak yang melibatkan struktur grup yang canggih kemungkinan akan mempersulit proses konsolidasi, yang dapat mengganggu ketertelusuran serta kualitas informasi pendapatan sebelum pajak yang digunakan untuk mengevaluasi kinerja grup perusahaan. Angka pendapatan sebelum pajak pada tingkat grup, seperti yang dilaporkan 
secara agregat kepada investor, pada akhirnya mungkin kurang berguna di mata pemegang saham.

Secara keseluruhan, peningkatan aktivitas penghindaran pajak dapat mengganggu kemampuan pemegang saham untuk menyimpulkan apakah dan sejauh mana penghindaran pajak pada akhirnya berkontribusi pada keuntungan. Secara umum, gagasan yang dimiliki pemegang saham tentang apakah, bagaimana, sejauh mana, dan komponen aktual dari angka laba bersih yang dipengaruhi oleh penghindaran pajak, tercermin dalam ERC lebih rendah. Informasi laba akan terganggu dalam sifat keinformatifannya dengan adanya penghindaran pajak yang semakin agresif (Kubata et al., 2013). Dengan demikian, hipotesis dalam penelitian ini adalah sebagai berikut:

H1: Penghindaran pajak berpengaruh negatif terhadap tingkat keinformatifan laba.

\section{METODOLOGI DAN ANALISIS DATA}

\subsection{Gambaran Umum Objek Penelitian}

Penelitian ini menggunakan metode kuantitatif. Penelitian ini akan menggunakan data sekunder yang bersumber dari laporan keuangan maupun laporan tahunan perusahaan yang listing di BEI dalam kurun waktu 2017 sampai dengan 2019. Data tersebut diperoleh dari situs Bursa Efek Indonesia (web.idx.co.id), The Indonesia Capital Market Institute (ticmi.co.id), Indonesian Capital Market Directory (ICMD), maupun dari sumber-sumber lainnya yang dianggap sesuai dengan penelitian yang dilakukan. Populasi pada penelitian ini adalah perusahaan sektor perdagangan yang terdaftar di BEI dalam jangka waktu tahun 2017 sampai dengan tahun 2019. Metode pengambilan sampel untuk penelitian ini menggunakan teknik purposive sampling, dengan kriteria sebagai berikut:

Tabel 1. Hasil Pemilihan Sampel

\begin{tabular}{lrr}
\hline \multicolumn{1}{c}{ Kriteria } & Jumlah & Ukuran \\
\hline Perusahaan sektor perdagangan yang terdaftar di BEI per 28 Desember 2020 & 72 & Perusahaan \\
Perusahaan yang terdaftar di BEI setelah 1 Januari 2014 & $(23)$ & Perusahaan \\
Elemen dan/atau informasi dalam LK tidak lengkap & $(1)$ & Perusahaan \\
Perusahaan dengan peredaran usaha kurang dari Rp4,8 Milyar dalam setahun & $(3)$ & Perusahaan \\
Perusahan yang mengalami kerugian atau melakukan kompensasi kerugian & $(26)$ & Perusahaan \\
Perusahaan dengan beban pajak negatif atau pajak lebih bayar & $(3)$ & Perusahaan \\
Jumlah perusahaan yang dapat digunakan dalam penelitian & 16 Perusahaan \\
Jumlah tahun observasi & 3 & Tahun \\
Total sampel & 48 & Observasi \\
\hline
\end{tabular}

Sumber: Hasil Olah Peneliti

Variabel dependen dalam penelitian ini adalah tingkat keinformatifan laba, sedangkan variabel independen dalam penelitian ini adalah agresivitas pajak. Tingkat keinformatifan laba diukur dengan Earnings Response Coefficients (ERC) sebagaimana Rullyan et al. (2017). Untuk mencari ERC, ada beberapa tahapan perhitungan yang harus dilakukan. Pertama, penelitian ini akan menghitung cumulative abnormal return (CAR) dari tiap-tiap sampel penelitian. Kedua, dengan menghitung unexpected earnings (UE) tiap sampel.

$$
\mathrm{CAR}_{1,[\mathrm{t}, 3, t+3]}=\sum_{t=-3}^{\mathrm{t}++3} \mathrm{AR}_{\mathrm{i}, \mathrm{t}}
$$

Di mana:

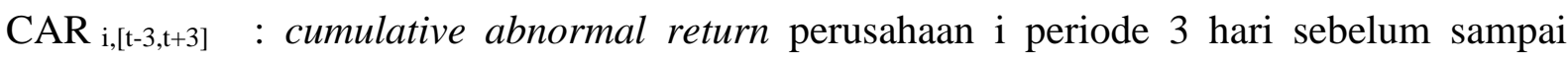
dengan periode 3 hari setelah laba akuntansi diumumkan pada waktu $\mathrm{t}$

$\mathrm{AR}_{\mathrm{it}} \quad$ : abnormal return perusahaan i pada hari ke-t 
Untuk mengukur abnormal return, penelitian ini menggunakan market-adjusted model karena model tersebut dapat menunjukkan estimasi return saham yang paling relevan adalah dengan menggunakan return indeks pasar pada waktu yang sama (Rullyan et al., 2017). Perhitungan AR untuk penelitian ini menggunakan rumus:

$$
A R_{1, t}=R_{1, t}-R_{m, t}
$$

Di mana:

$\mathrm{AR}_{\mathrm{it}} \quad$ : abnormal return untuk perusahaan i pada periode ke-t

$\mathrm{R}_{\mathrm{it}} \quad$ : return (tingkat pengembalian) perusahaan i pada periode ke- $\mathrm{t}$

$\mathrm{R}_{\mathrm{mt}} \quad$ : return (tingkat pengembalian) pasar pada periode ke- $\mathrm{t}$

Berdasarkan market-adjusted model, untuk memperoleh abnormal return, dilakukan perhitungan return saham tahunan dan return ekspektasi yang didasarkan pada indeks pasar dengan formula:

$$
\mathrm{R}_{\mathrm{i}, \mathrm{t}}=\frac{\mathrm{P}_{\mathrm{t}}-\mathrm{P}_{\mathrm{t}-1}}{\mathrm{P}_{\mathrm{t}-1}}
$$

Di mana:

$\mathrm{R}_{\text {it }} \quad$ : return (tingkat pengembalian) tahunan perusahaan i periode $\mathrm{t}$

$\mathrm{P}_{\mathrm{t}} \quad$ : Harga penutupan saham perusahaan i pada tahun $\mathrm{t}$

$\mathrm{P}_{\mathrm{t}-1} \quad$ : Harga penutupan saham perusahaan i pada tahun $\mathrm{t}-1$

Di mana:

$$
R_{\mathrm{M}, \mathrm{t}}=\frac{\mathrm{IHSG}_{\mathrm{t}}-\mathrm{IHSG}_{\mathrm{t}-1}}{\mathrm{IHSG}}
$$

$\mathrm{R}_{\mathrm{Mt}} \quad$ : Return indeks pasar pada hari ke-t

$\mathrm{IHSG}_{\mathrm{t}}$ : Indeks harga saham gabungan pada tahun $\mathrm{t}$

$\mathrm{IHSG}_{\mathrm{t}-1} \quad$ : Indeks harga saham gabungan pada tahun $\mathrm{t}-1$

Untuk menghitung Unexpected Earning (UE), penelitian ini menggunakan pengukuran laba akuntansi dengan mencari selisih laba per lembar saham. Laba kejutan (Unexpected Earning) merupakan perbedaan laba per lembar saham pada periode penelitian dan laba per lembar saham pada periode sebelumnya. Formula perhitungan UE sebagai berikut:

Di mana:

$$
\mathrm{UE}_{\mathrm{It}}=\frac{\mathrm{EPS}_{\mathrm{t}}-\mathrm{EPS}_{\mathrm{t}-\mathrm{l}}}{\mathrm{EPS}_{\mathrm{t}-1}}
$$

$\mathrm{UE}_{\mathrm{it}} \quad=$ Unexpected earnings perusahaan i pada periode ke- $\mathrm{t}$

$\mathrm{EPS}_{\mathrm{it}}=$ laba per lembar saham perusahaan i pada periode ke-t

$\mathrm{EPS}_{\mathrm{it}-1}=$ laba per lembar saham i pada periode sebelumnya

Selanjutnya, ERC merupakan koefisien yang diperoleh dari slope $\beta$ antara cummulative abnormal return (CAR) dan unexpected earnings (UE) sebagaimana dinyatakan dalam model empiris (Teests \& Weasly, 1996), yaitu:

$$
\mathbf{C A R}_{\mathrm{it}}=\mathbf{a}+\mathbf{b U E _ { i t }}+\varepsilon_{\mathrm{it}}
$$

Di mana:

$\mathrm{CAR}_{\mathrm{it}}$ : abnormal return kumulatif perusahaan i selama periode 3 hari sebelum dan 3 hari setelah laba akuntansi diumumkan pada waktu $\mathrm{t}$

$\mathrm{UE}_{\mathrm{it}} \quad$ : unexpected earnings

b : Earnings Response Coefficients (ERC)

$\varepsilon_{\text {it }} \quad$ : komponen error dalam model atas perusahaan i pada periode $\mathrm{t}$

Penelitian terdahulu mengenai agresivitas pajak sangat beragam, Rego \& Wilson (2009) menggunakan enam variabel untuk mengukur agresivitas pajak, yaitu Effective Tax Rate (ETR), Cash Effective Tax Rate (CashETR), Book-tax Differences (BTDs), Permanent 
BTDs (PBTD), Discretionary Permanent BTDs (DTAX), dan Predicted Tax Shelter Firms. Sementara Dunbar et al. (2010) mengukur agresivitas pajak menggunakan sembilan variabel, yaitu BETR (Book Effective Tax Rate), CETR (Current Book Effective Tax Rate), CashETR, LRCashETR (Five Year Average Cash Effective Tax Rate), BTD , PBTD (Permanent Book Tax Difference), DTAX (Discretionary Permanent Difference), ABTD (Abnormal Book Tax Difference), dan SHELTER.

Penelitian yang dilakukan di Indonesia banyak menggunakan basis Effective Tax Rate (ETR) sebagai variabel agresivitas pajak. Berkaitan dengan penggunaan basis ETR sebagai ukuran agresivitas pajak, Dunbar et al. (2010) mengungkapkan bahwa semakin tinggi agresivitas pajak perusahaan akan menghasilkan ukuran yang berbasis ETR lebih kecil dan ukuran yang berbasis selain ETR yang semakin besar. Pengukuran agresivitas pajak dengan menggunakan basis ETR akan memberikan hasil yang berbanding terbalik, di mana perusahaan yang memiliki ETR semakin kecil, berarti agresivitas pajak perusahaan tersebut semakin besar, dan sebaliknya.

Dyreng et al. (2008) menyebutkan bahwa ETR adalah yang pertama harus dipertimbangkan dalam mengukur agresivitas pajak, karena perusahaan diharuskan untuk mengungkap beban pajaknya dalam laporan keuangan. Tetapi, ETR mempunyai beberapa kelemahan, salah satunya adalah ETR diukur hanya berdasarkan data tahunan dan akan terdapat variasi yang signifikan pada ETR setiap tahunnya. Selain itu, ETR juga tidak mempertimbangkan adanya temporary book-tax difference (beda temporer), hal ini karena beban pajak yang dilaporkan pada laporan keuangan perusahaan mengandung beban pajak kini dan beban pajak tangguhan. Beban pajak tangguhan merupakan hasil dari adanya beda temporer.

Dyreng et al. (2008) melakukan beberapa modifikasi pada perhitungan ETR untuk mengatasi kelemahan tersebut. Pertama, ETR diukur untuk jangka waktu yang lebih panjang, lebih dari satu tahun, dengan cara menjumlahkan seluruh pajak yang dibayar perusahaan dalam jangka waktu tertentu, dibagi dengan laba sebelum pajak (tidak termasuk transaksi atas kejadian luar biasa) selama jangka waktu yang sama. Hal tersebut akan menghasilkan ETR yang lebih menggambarkan beban pajak perusahaan selama jangka waktu tersebut. Kedua, mengganti ukuran ETR dari beban pajak menjadi pajak yang dibayar oleh perusahaan.

Dalam praktiknya, perusahaan tidak mengungkapkan secara eksplisit berapa jumlah pajak yang sebenarnya dibayar, namun perusahaan seharusnya memisahkan berapa jumlah beban pajak kini dan beban pajak tangguhan perusahaan pada suatu periode. Penggunaan beban pajak kini sebagai ukuran ETR dapat menghilangkan kelemahan ETR yang tidak mempertimbangkan adanya beda temporer. Oleh karena itu, penelitian ini menggunakan proksi Current Book Effective Tax Rate yang mewakili agresivitas pajak sebagaimana Dunbar et al., (2016) sebagai berikut:

$$
\text { CET Rit }=\frac{\text { Current Income } \text { Tax Expense } i, t}{\text { Pretax } \text { Income } i, t}
$$

Selanjutnya, variabel kontrol yang digunakan dalam penelitian ini meliputi ukuran perusahaan, leverage, dan profitabilitas. Ukuran perusahaan merupakan skala dimana besar kecilnya suatu perusahaan dapat diklasifikasikan menurut berbagai cara salah satunya melalui total asset. Variabel ukuran perusahaan diukur dengan proxy logaritma natural (ln) dari total aset dengan nilai rupiah penuh, proxy ini sebagaimana Jalil (2013) dan Lasmida et al. (2020).

Ukuran perusahaan $($ SIZE $)=\ln ($ Total Aset $)$

Leverage menunjukan kemampuan perusahaan untuk memenuhi kewajiban jangka panjangnya dengan aset yang dimilikinya (Anggreni, 2014). Pemanfataan dana yang berasal dari utang dapat meningkatkan pendapatan perusahaan atau ekuitas perusahaan (Purwandari 
\& Purwanto, 2012). Pengukuran leverage dalam penelitian ini mengikuti Lasmida et al. (2020), Anggreni (2014), dan Djayanti (2015) yaitu:

$$
\text { Lev }=\frac{\text { Total Hutang }}{\text { Total Aset }}
$$

Profitabilitas dapat dianggap sebagai hubungan antara pendapatan dan biaya yang timbul dari penggunaan aset, baik aset lancar maupun aset tidak lancar, dalam aktivitas operasi. Novy-Marx, (2013) mendefinisikan profitabilitas (gross profitability) sebagai laba kotor yang dibandingkan dengan nilai buku dari total aset, memiliki kekuatan prediksi yang lebih baik daripada laba bersih. Proksi profitabilitas dalam penelitian ini menggunakan Return of Assets (ROA) sebagaimana Dunbar et al. (2010), Dyreng et al. (2008) dan Pandana \& Santioso (2020).

$$
\text { ROAit }=\frac{\text { Pretax } \text { Income }}{\text { Total Asset }}
$$

Penelitian ini dilakukan untuk mengetahui pengaruh variabel independen Agresivitas Pajak (CETR) terhadap tingkat keinformatifan laba (ERC) sebagai variabel dependen dengan menggunakan tiga variabel kontrol yakni ukuran perusahaan (Size), leverage perusahaan (Lev) dan profitabilitas (ROA). Metode analisis data yang digunakan dalam penelitian ini adalah menggunakan analisis regresi berganda (multi-regression). Model penelitian ini adalah sebagai berikut:

$$
\mathrm{CAR}_{i t}=\alpha+\beta 1 \mathrm{CETR}_{\mathrm{it}}+\beta 2 \mathrm{UE}_{\mathrm{it}}+\beta 3\left(\mathrm{CETR}_{\mathrm{it}} * \mathrm{UE}_{\mathrm{it}}\right)+\beta 4 \mathrm{Size}_{\mathrm{it}}+\beta 5 \mathrm{Lev}_{\mathrm{it}}+\beta 6 \mathrm{ROA}_{\mathrm{it}}+\varepsilon_{\mathrm{it}}
$$

Keterangan:

B3 : earnings response coefficient tiap perusahaan i pada tahun $\mathrm{t}$

$\mathrm{CAR}_{\text {it }}$ : abnormal return kumulatif perusahaan i selama periode 3 hari sebelum dan 3 hari setelah laba akuntansi diumumkan pada waktu $\mathrm{t}$

$\mathrm{UE}_{\mathrm{it}} \quad$ : unexpected earnings

CETR $_{\text {it }}$ : current book effective tax rate perusahaan i pada tahun $\mathrm{t}$

Size $_{\text {it }}$ : ukuran perusahaan i pada tahun $\mathrm{t}$

Levit $_{\text {it }}:$ leverage perusahaan i pada tahun $\mathrm{t}$

$\mathrm{ROA}_{\text {it }}$ : profitabilitas perusahaan i pada tahun $\mathrm{t}$

\section{HASIL PENELITIAN DAN DISKUSI}

\subsection{Statistik Deskriptif}

Statistik deskriptif untuk variabel dalam penelitian ini terdapat dalam Tabel 2.

Tabel 2 Statistik Deskriptif

\begin{tabular}{lcccccc}
\hline & CAR & CETR & UE & LEV & ROA & SIZE \\
\hline Mean & 0.011 & 0.258 & 0.0039 & 0.468 & 0.104 & 29.023 \\
Med & 0.021 & 0.243 & 0.0029 & 0.424 & 0.089 & 29.251 \\
Max. & 0.165 & 0.650 & 0.213 & 0.811 & 0.441 & 30.729 \\
Min. & -0.190 & 0.1001 & -0.161 & 0.164 & 0.0097 & 26.734 \\
Std. Dev. & 0.081 & 0.097 & 0.0557 & 0.194 & 0.088 & 1.162 \\
Obs. & 48 & 48 & 48 & 48 & 48 & 48 \\
\hline
\end{tabular}

\section{Sumber: diolah}

Berdasarkan hasil statistik deskriptif, jumlah sampel pengamatan (N) sebesar 48. Pengukuran agresivitas pajak menggunakan basis CETR akan memberikan hasil yang berbanding terbalik, di mana perusahaan yang memiliki ETR semakin kecil berarti agresivitas pajak perusahaan tersebut semakin besar. Berdasarkan Tabel 2, nilai CETR berkisar antara $10,0 \%$ hingga $65,1 \%$. Nilai rata-rata variabel agresivitas pajak (CETR) sebesar 25,82\%. Nilai 
tersebut lebih tinggi sedikit daripada tarif pajak efektif yang berlaku di Indonesia. Perbedaan yang tidak signifikan tersebut menunjukkan bahwa secara rata-rata perusahaan sektor perdagangan di Indonesia tidak melakukan tindakan penghindaran pajak yang agresif.

\subsection{Pemilihan Model Regresi Data Panel}

\section{a. Uji Chow}

Uji Chow merupakan pengujian untuk menentukan Fixed Effect Model atau Common Effect Model yang paling tepat digunakan dalam mengestimasi data panel. Hasil uji ditunjukkan pada tabel 3.

Tabel 3. Hasil Uji Chow

\begin{tabular}{lrrc}
\hline Effects Test & Statistic & d.f. & Prob. \\
\hline Cross-section F & 1.574 & $(15,28)$ & 0.145 \\
Cross-section Chi-square & 29.359 & 15 & 0.014 \\
\hline
\end{tabular}

Sumber: diolah

Hasil uji chow pada penelitian ini menunjukkan nilai probabilitas pada cross-section $F$ adalah sebesar 0.1455 , yang artinya nilai probabilitasnya lebih besar daripada nilai signifikansi sebesar 5\%. Hal tersebut berarti $\mathrm{H} 0$ diterima, maka model regresi yang cocok digunakan adalah common effect model.

\section{b. Uji Hausman}

Uji hausman digunakan untuk menentukan apakah fixed effect model atau random effect model yang lebih tepat digunakan untuk menjalankan model regresi. Untuk menentukan hipotesis mana yang akan diterima dalam uji hausman, dilihat dari nilai probablitas chi-square pada cross-section random dari hasil uji hausman dan dibandingkan dengan nilai signifikansi $\alpha$ sebesar $5 \%(\alpha=0,05)$.

Tabel 1. Hasil Uji Hausman

Test cross-section random effects

\begin{tabular}{lrrr}
\hline Test Summary & Chi-Sq. Statistic Chi-Sq. d.f. & Prob. \\
Cross-section random & 0.831 & 4 & 0.934 \\
\hline
\end{tabular}

Sumber: diolah

Pada penelitian ini, nilai probablitas chi-square pada cross-section random yang dihasilkan dari uji hausman adalah sebesar 0.9343 , lebih besar dari nilai signifikansi $5 \%$. Artinya, pada penelitian ini, model regresi yang lebih tepat untuk digunakan adalah random effect model.

\section{c. Uji Breusch-Pagan Lagrange Multiplier}

Uji breusch-pagan lagrange multiplier adalah uji yang dilakukan untuk menentukan model regresi yang lebih tepat digunakan di antara common effect model dan random effect model. Uji ini dilakukan dengan membandingkan probabilitas breusch-pagan dengan nilai signifikansi $\alpha$ sebesar $5 \%(\alpha=0,05)$.

Tabel 2. Hasil Uji Breusch-Pagan Lagrange Multiplier

\begin{tabular}{lccc}
\hline \multicolumn{3}{c}{ Test Hypothesis } \\
\hline \multirow{3}{*}{ Breusch-Pagan } & Cross-section & Time & Both \\
& 1.263 & 0.263 & 1.525 \\
& $(0.261)$ & $(0.608)$ & $(0.216)$ \\
\hline
\end{tabular}

Sumber: diolah 
Nilai probabilitas breusch-pagan yang dihasilkan pada penelitian ini lebih besar dari nilai signifikansi $5 \%$. Karena itu, pada penelitian ini, $\mathrm{H}_{0}$ diterima dan model regresi yang akan digunakan dalam penelitian ini adalah common effect model. Setelah ketiga uji untuk menentukan model regresi tersebut dilakukan maka dapat disimpulkan bahwa common effect model merupakan model yang terpilih untuk digunakan dalam penelitian ini. Hal tersebut dikarenakan hasil uji Chow menyatakan bahwa model common effect model yang terpilih. Sementara itu, uji Hausman menyatakan bahwa model random effect model. Selanjutnya dilakukan uji Breusch-Pagan Lagrange Multiplier dan terpilih common effect model sebagai model yang paling tepat untuk analisis regresi yang digunakan dalam penelitian.

\subsection{Hasil Uji Asumsi Klasik}

\section{a. Uji Normalitas}

Dari hasil uji normalitas didapatkan bahwa probability sebesar 0,003698 (lebih kecil dari signifikansi 0,05) dan nilai Jarque-Bera sebesar 19,60013 sehingga model regresi tidak memiliki bentuk normal. Tetapi untuk regresi data panel, model dengan Prob tersebut tetap bisa digunakan.

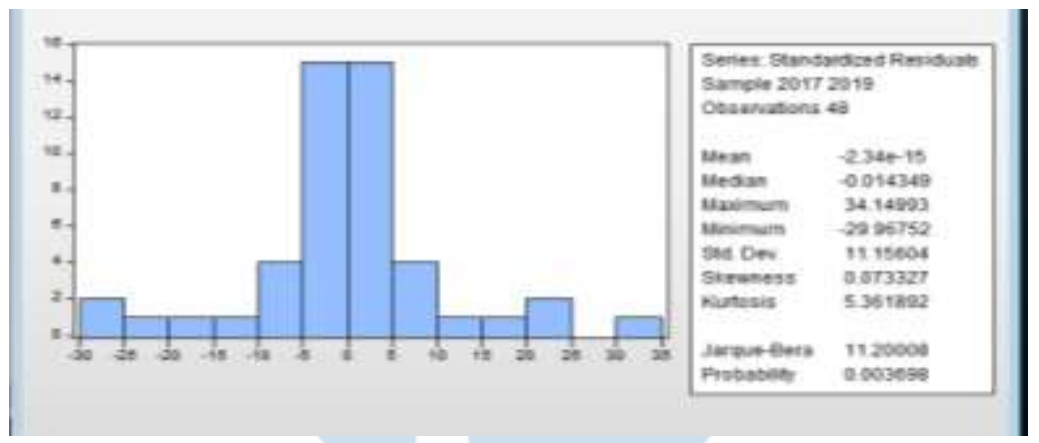

Gambar 1. Hasil Uji Normalitas

Sumber: diolah

\section{b. Uji Multikolinieritas}

Uji multikolinieritas bertujuan untuk menguji keberadaan korelasi antara variabel independen dan model regresi. Hasil uji multikolinearitas adalah sebagai berikut:

Tabel 6. Hasil Uji Multikolinearitas

\begin{tabular}{ccrrrrr}
\hline & CAR & CETR & UE & \multicolumn{1}{c}{ LEV } & \multicolumn{1}{c}{ ROA } & \multicolumn{1}{c}{ SIZE } \\
\hline CAR & 1.000 & 0.219 & -0.123 & -0.123 & -0.258 & -0.276 \\
CETR & 0.219 & 1.000 & 0.001 & -0.115 & -0.202 & -0.067 \\
UE & -0.123 & 0.001 & 1.000 & 0.044 & 0.144 & 0.084 \\
LEV & -0.123 & -0.115 & 0.044 & 1.000 & -0.140 & 0.214 \\
ROA & -0.258 & -0.202 & 0.144 & -0.140 & 1.000 & 0.237 \\
SIZE & -0.276 & -0.067 & 0.084 & 0.214 & 0.237 & 1.000 \\
\hline
\end{tabular}

Sumber: diolah

Dari tabel diatas, dapat diketahui bahwa tidak terdapat korelasi antara variabel independen karena nilai Probability tidak ada yang diatas 0,80 sehingga model regresi tidak mengalami multikolinearitas.

\section{c. Uji Heteroskedastisitas}

Uji heteroskedastisitas bertujuan untuk menguji apakah dalam model regresi terdapat ketidaksamaan variance dari residual satu pengamatan ke pengamatan yang lain. Dari hasil output Eviews, diketahui bahwa model regresi mengandung heteroskedastistitas sehingga 
dilakukan transformasi model regresi menggunakan Panel EGLS (cross-section weights). Dari hasil transformasi tersebut, model regresi data panel sudah bisa digunakan untuk analisis lebih lanjut.

\subsection{Uji Hipotesis}

Berdasarkan pengujian pada ketiga model dengan menggunakan uji Chow, uji Hausman, dan uji Breusch-Pagan Lagrange Multiplie, bahwa common effect model merupakan model yang terpilih untuk digunakan dalam penelitian ini. Tabel 7 merupakan hasil uji hipotesis dalam penelitian ini.

Tabel 7. Hasil Uji Hipotesis

\begin{tabular}{crrl}
\hline Var. & \multicolumn{1}{l}{ Coeff. } & \multicolumn{1}{c}{ t-Stat. } & Prob. \\
\hline C & -0.087 & -0.521 & 0.605 \\
CETR & 0.234 & 3.034 & $0.002^{* * *}$ \\
UE & -1.572 & -1.694 & $0.049^{* * *}$ \\
CETR*UE & 4.939 & 1.751 & $0.044^{* *}$ \\
LEV & 0.008 & 0.198 & 0.422 \\
ROA & -0.224 & -1.717 & $0.047^{* *}$ \\
SIZE & 0.002 & 0.391 & 0.349 \\
\hline R $^{2}$ & $\mathbf{0 . 3 8 8}$ & & \\
Adj. $\mathbf{R}^{\mathbf{2}}$ & $\mathbf{0 . 2 9 8}$ & & \\
F-stat. & $\mathbf{4 . 3 2 7}$ & & \\
Prob(F-stat.) & $\mathbf{0 . 0 0 2}$ & & \\
\hline Keterangan: & & &
\end{tabular}

Keterangan:

*) signifikansi pada $\alpha=10 \%$, **) signifikansi pada $\alpha=$ $5 \%, * * *)$ signifikansi pada $\alpha=1 \%$

Sumber: diolah

Hasil pengujian statistik pada model penelitian ini menunjukan variabel CETR*UE mempunyai nilai koefisien sebesar 4.939, t-statistik 1.751, dan probabilitas sebesar 0.044. Nilai koefisien sebesar 4.939 merupakan Koefisien Respon Laba (ERC) dimana CETR diinteraksikan dengan variabel UE. Nilai probabilitas 0.0437 kurang dari tingkat signifikansi sebesar 0,05 , sehingga variabel CETR*UE secara parsial berpengaruh positif signifikan terhadap CAR. Variabel CETR*UE berbanding terbalik dengan tingkat agresivitas pajak, semakin kecil CETR dapat dikatakan tingkat agresivitas pajak tinggi dan sebaliknya. Dengan demikian, dapat disimpulkan bahwa semakin tinggi tingkat agresivitas pajak perusahaan maka tingkat keinformatifan laba (ERC) suatu perusahaan menjadi lebih rendah. Terkait dengan pengujian variabel kontrol, variabel ROA berpengaruh signifikan terhadap CAR. Sementara itu, variabel LEV dan SIZE tidak berpengaruh terhadap CAR.

Pengujian hipotesis menunjukkan bahwa agresivitas pajak berpengaruh negatif terhadap tingkat keinformatifan laba. Hasil pengujian dalam penelitian ini sejalan dengan Kubata et al. (2013). Hasil pengujian ini mengkonfirmasi teori sinyal yang menyatakan bahwa sinyal yang tercermin dalam informasi yang diberikan manajemen perusahaan kepada publik terkait dengan kebijakan tertentu dapat dianalisis oleh investor dalam menilai kinerja perusahaan. Hasil interpretasi dan analisis atas informasi yang diterima sebagai sinyal baik atau buruk oleh investor akan digunakan dalam proses pengambilan keputusan investasi (Scott, 2015). Salah satu yang menjadi dasar analisis investor terkait dengan sinyal kebijakan manajer adalah tindakan agresivitas pajak. Investor menerjemahkan sinyal tindakan 
penghindaran pajak secara agresif oleh manajemen sebagai suatu upaya yang dapat menurunkan tingkat keinformatifan laba dengan adanya transaksi pajak yang kompleks.

Agresivitas pajak dapat memberikan manfaat marjinal dan biaya marjinal (Chen et al., 2010). Manfaat marjinal yang dapat diperoleh berasal dari penghematan pajak yang dibayarkan perusahaan kepada pemerintah, manajer yang diberi kompensasi oleh pemilik/pemegang saham atas tindakan pajak yang agresif, dan kesempatan bagi manajer untuk melakukan rent extraction (Hidayanti, 2013). Namun di sisi lain, investor menganggap bahwa tindakan agresivitas pajak merupakan kebijakan sepihak manajer yang menimbulkan adanya informasi asimetri. Tindakan agresivitas pajak memiliki tujuan tertentu yang tidak sejalan dengan kepentingan pemegang saham. Biaya marjinal dari tindakan agresivitas pajak tersebut antara lain kemungkinan perusahaan mendapatkan sanksi dari otoritas pajak dan penurunan harga saham perusahaan. Turunnya harga saham diakibatkan oleh anggapan pemegang saham bahwa aktivitas agresivitas pajak yang dilakukan oleh manajer untuk rent extraction tersebut dapat merugikan kepentingan pemegang saham (Desai \& Dharmapala, 2009). Selain itu, walaupun tidak terdapat pelanggaran aturan peraturan perundangan dan standar akuntansi, tindakan agresivitas pajak erat kaitannya dengan tindakan oportunistik manajer untuk tujuan-tujuan tersebut (Firmansyah \& Bayuaji, 2019). Oleh karena itu, informasi laba rugi yang dihasilkan perusahaan tidak direspon positif oleh investor. Kondisi ini mengakibatkan nilai ERC menjadi lebih rendah untuk perusahaan yang memiliki tingkat agresivitas pajak lebih besar.

Dari data sampel penelitian, nilai CETR yang berkisar antara $10 \%$ sampai dengan $20 \%$ (dapat diasumsikan sebagai perusahaan dengan tingkat agresivitas pajak yang lebih tinggi) memiliki nilai ERC yang rendah. Tingkat agresivitas pajak yang relatif tinggi (sebagaimana tercermin pada CETR yang lebih rendah) berpengaruh terhadap tingkat responsivitas laba secara signifikan yang lebih rendah, yaitu penurunan keinformatifan laba. Kompleksitas transaksi agresivitas pajak yang dilakukan oleh manajer akan membuat investor lebih sulit untuk memahami kualitas laba yang dilaporkan oleh perusahaan, baik pada level beban pajak maupun pendapatan sebelum pajak. Oleh karena itu, laba yang dilaporkan oleh perusahaan melakukan agresivitas pajak menjadi berkurang tingkat keinformatifannya bagi para investor dalam pengambilan keputusan. Selain itu, perusahaan yang membayar pajak dalam jumlah yang sangat tinggi (akibat penghindaran pajak yang "gagal") memiliki kewajiban pajak yang lebih besar di masa yang akan datang. Jika investor mengetahui bahwa ada kemungkinan aliran kas tambahan yang harus dibayarkan kepada otoritas pajak (akibat penghindaran pajak yang agresif), maka laba perusahaan menjadi kurang informatif di perusahaan-perusahaan ini bagi para investor.

\section{KESIMPULAN DAN SARAN}

\subsection{Kesimpulan}

Perusahaan yang melakukan tindakan penghindaran pajak yang lebih agresif memiliki tingkat keinformatifan laba yang lebih rendah bagi investor. Kompleksitas transaksi penghindaran pajak yang dilakukan oleh perusahaan mengakibatkan adanya informasi asimetri antara manajer dan pemegang saham. Tindakan tersebut juga akan membuat investor lebih sulit untuk memahami kualitas laba yang dilaporkan oleh perusahaan, baik pada level beban pajak maupun pendapatan sebelum pajak. Oleh karena itu, laba yang dilaporkan oleh perusahaan yang secara agresif melakukan perencanaan pajak menjadi kurang dapat digunakan sebagai pengambilan keputusan investasi. Hasil penelitian ini dapat dijadikan referensi bagi investor dalam rangka pengambilan keputusan investasinya, terutama terkait indikasi kegiatan agresivitas pajak oleh perusahaan. Perusahaan dapat menyajikan informasi 
tambahan (baik informasi keuangan maupun non-keuangan) agar informasi laba yang dilaporkan dapat direspon lebih baik oleh investor. Penelitian ini menyarankan agar Otoritas Jasa Keuangan dapat meningkatkan edukasi kepada investor dalam penggunaan informasi yang bersumber dari laporan keuangan terutama dalam rangka pengambilan keputusan investasi. Dewan Standar Akuntansi Indonesia juga diharapkan dapat mengatur pengungkapan informasi yang bersumber dari laporan keuangan agar dapat lebih mudah dipahami oleh pengguna laporan keuangan, khususnya oleh investor.

\subsection{Keterbatasan dan Saran Untuk Penelitian Selanjutnya}

Penelitian ini hanya menggunakan sampel dalam jumlah yang kecil dan pada satu sektor saja, sehingga hasil pengujian ini tidak menggeneralisasi untuk hasil pengujian dengan menggunakan data dan informasi perusahaan lainnya. Penelitian selanjutnya dapat menggunakan data perusahaan yang lebih banyak sehingga penelitian selanjutnya dapat mendapatkan hasil pengujian yang lebih baik. Penelitian selanjutnya juga diharapkan dapat menambah variabel-variabel penelitian lain terutama yang berhubungan dengan konsekuensi dari agresivitas pajak pajak seperti Permanent BTDs (PERM_BTD), Book-tax Differences (BTDs), Predicted Tax Shelter Firms, atau Discretionary Permanent BTDs (DTAX).

\section{REFERENSI}

Atwood, T. J., Drake, M. S., \& Myers, L. A. (2010). Book-tax conformity, earnings persistence and the association between earnings and future cash flows. Journal of Accounting and Economics, 50(1), 111-125.

Balakrishnan, K., Blouin, J. L., \& Guay, W. R. (2011). Does tax aggressiveness reduce financial reporting transparency? Wharton School, University of Pennsylvania.

Balakrishnan, K., Blouin, J. L., \& Guay, W. R. (2019). Tax aggressiveness and corporate transparency. The Accounting Review, 94(1), 45-69.

Ball, R., \& Brown, P. (1968). An empirical evaluation of accounting income numbers. Journal of Accounting Research, 159-178.

Collins, D. W., \& Kothari, S. P. (1989). An analysis of intertemporal and cross-sectional determinants of earnings response coefficients. Journal of Accounting and Economics, 11(2-3), 143-181.

Dechow, P., Ge, W., \& Schrand, C. (2010). Understanding earnings quality: A review of the proxies, their determinants and their consequences. Journal of Accounting and Economics, 50(2-3), 344-401.

Desai, M. A., \& Dharmapala, D. (2009). Corporate Tax Avoidance and Firm Value Discount. Review of Economics and Statistics, 91(3), 537-546. https://doi.org/10.1142/S2010139220500081

Dunbar, A., Higgins, D., Phillips, J., \& Plesko, G. (2010). What do measures of tax aggressiveness measure. Proceedings of the National Tax Association Annual Conference on Taxation, 103(103), 18-26.

Dyreng, S. D., Hanlon, M., \& Maydew, E. L. (2008). Long-run corporate tax avoidance. The Accounting Review, 83(1), 61-82.

Firmansyah, A. (2017). Pengaruh Income smoothing dan real earnings management terhadap keinformatifan laba. Jurnal Online Insan Akuntan, 2(2), 175 - 188.

Firmansyah, A., \& Bayuaji, R. (2019). financial constraints, investment opportunity set, financial reporting aggressiveness, tax aggressiveness: evidence from Indonesia 
Manufacturing Companies. Academy of Accounting and Financial Studies Journal, 23(5), 1-18.

Firmansyah, A., \& Triastie, G. A. (2020). The role of corporate governance in emerging market: tax avoidance, corporate social responsibility disclosures, risk disclosures, and investment efficiency. Journal of Governance and Regulation, 9(3), 8-26.

Firmansyah, A., \& Yusuf (2020). The value relevance of corporate disclosures: social responsibility, intellectual capital, corporate governance. ASSETS, Jurnal Akuntansi dan Pendidikan, 9(1), 61-71.

Firmansyah, A., Utami, W., Umar, H., \& Mulyani, S. D. (2020). The role of derivative instruments on risk relevance from emerging market non-financial companies. Journal of Governance and Regulation, 9(2), 45-63.

Frank, M. M., Lynch, L. J., \& Rego, S. O. (2009). Tax reporting aggressiveness and its relation to aggressive financial reporting. The Accounting Review, 84(2), 467-496.

Hanlon, M., Maydew, E. L., \& Shevlin, T. (2008). An unintended consequence of book-tax conformity: A loss of earnings informativeness. Journal of Accounting and Economics, 46(2-3), 294-311.

Hanlon, M., \& Slemrod, J. (2009). What does tax aggressiveness signal? Evidence from stock price reactions to news about tax shelter involvement. Journal of Public Economics, 93(1-2), 126-141.

Ihdina, M., Afifudin, \& Junaidi (2019). Pengaruh pengungkapan corporate social responsibility, profitabilitas, dan leverage terhadap keinformatifan laba dengan kinerja lingkungan sebagai variabel moderasi. E-JRA, 8(4), 80-88.

Jalil, M. R. (2013). Pengaruh persistensi laba, growth opportunities , dan ukuran perusahaan terhadap relevansi nilai laba akuntansi. Jurnal Akuntansi, September, 1-29.

Jananto, A. E., \& Firmansyah, A. (2019). The effect of bonuses, cost of debt, tax avoidance, and corporate governance on financial reporting aggressiveness: evidence from Indonesia. International Journal of Innovation, Creativity and Change, 7(5), 280-302.

Karasek R., \& Bryant, P. (2015). Signaling theory: Past, present, and future. Electronic Business Journal, 14(15), 550-558.

Kim, J.-B., Li, Y., \& Zhang, L. (2011). Corporate tax avoidance and stock price crash risk: Firm-level analysis. Journal of Financial Economics, 100(3), 639-662.

Kothari, S. P., \& Sloan, R. G. (1992). Information in prices about future earnings: Implications for earnings response coefficients. Journal of Accounting and Economics, 15(2-3), 143-171.

Kubata, A. D., Lietz, G. M., \& Watrin, C. (2013). Does Corporate Tax Avoidance Impair Earnings Informativeness? SSRN Electronic Journal. https://doi.org/10.2139/ssrn.2363873

Lasmida, F., Ekadjaja, A., \& Tarumanagara, U. (2020). Pengaruh Profitabilitas, Leverage Dan Ukuran Perusahaan Terhadap Earnings Response Coefficient Perusahaan Jasa. 2, 1698-1707.

Lestari, A. (2018). Pengaruh pemberian ESOP dan kualitas auditor terhadap keinformatifan laba dimoderasi kepemilikan manajerial. Jurnal Informasi Perpajakan, Akuntansi dan Keuangan Publik, 13(2), 163-180.

Lietz, G. M. (2013). Determinants and consequences of corporate tax avoidance. Available at SSRN 2363868. 
Novy-Marx, R. (2013). The other side of value: The gross profitability premium. Journal of Financial Economics, 108(1), 1-28.

Pandana, B. P., \& Santioso, L. (2020). Faktor Yang Mempengaruhi Firm Performance Pada Perusahaan Manufaktur Yang Terdaftar Di Bei. Jurnal Multiparadigma Akuntansi Tarumanagara, 2(1), 1809-1817. https://doi.org/10.24912/jmieb.v2i1.1741

Patel, S., Devada, S., Patel, H., Patel, N., Bhavsar, S., \& Thaker, A. (2011). Influence of coadministration of piperine on pharmacokinetic profile of gatifloxacin in layer birds. Global Veterinaria, 7(5), 427-432.

Rahmawati, Q., \& Asyik, N. F. (2019). Pengaruh struktur modal, profitabilitas, risiko sistematis, dan pertumbuhan perusahaan terhadap earnings response coefficient. Jurnal Ilmu Riset Dan Akuntansi, 9(1), 1-18.

Rego, S. O., \& Wilson, R. (2009). Executive compensation, tax reporting aggressiveness, and future firm performance. Research Gate.

Saksessia, D., \& Firmansyah, A. (2020). the role of corporate governance on earnings quality from positive accounting theory framework. International Journal of Scientific \& Technology Research, 9(1), 808-820.

Scholes, M., Wolfson, M., Erickson, M., Maydew, E., \& Shevlin, T. (2009). Taxes and business strategy: A planning approach. Pearson Prentice-Hall. Upper Saddle River, NJ.

Scott, W.R. 2015. Financial Accounting Theory, 7th Ed. Toronto: Pearson Prentice Hall.

Septilestrai, D., Maharani, B., \& Agustini, A. T. (2018). Analisis pengaruh pengungkapan, transaksi dan saldo pihak berelasi terhadap harga saham sektor keuangan di BEI. Jurnal Akuntansi Universitas Jember, 16(1), 13-29.

Suharti, I. K., \& Arieftiara, D. (2019). Simultaneous Effect between Financial Reporting Aggressiveness and Tax Reporting Aggressiveness: The Impact on The Earnings Informativeness. The Indonesian Journal of Accounting Research, 22(1), 1-30. https://doi.org/10.33312/ijar.427

Wagener, T., \& Watrin, C. (2014). The relevance of complex group structures for income shifting and investors' valuation of tax avoidance. Working Paper.

Zimmerman, J. L. (1983). Taxes and firm size. Journal of Accounting and Economics, 5, 119-149.

Yanti, M., \& Taqwa, S. (2020). Pengaruh struktur kepemilikan perusahaan dan karakteristik komite audit terhadap keinformatifan laba akuntansi. Jurnal Eksplorasi Akuntansi, 2(4), $3628-3641$. 